\title{
Prostate Cancer Cells Regulate Growth and Differentiation of Bone Marrow Endothelial Cells Through TGF $\beta$ and Its Receptor, TGF $\beta$ RII
}

\author{
Jeffrey M. Barrett, ${ }^{1,2}$ Mark A. Rovedo, ${ }^{1}$ Aamair M. Tajuddin, ${ }^{2}$ Tamas Jilling, ${ }^{1,3}$ \\ Jill A. Macoska, ${ }^{4,5}$ James MacDonald, ${ }^{5}$ Kathy A. Mangold, ${ }^{2}$ \\ and Karen L. Kaul ${ }^{1,2,6 *}$ \\ IInterdepartmental Biological Sciences Program, Northwestern University, Evanston, Illinois \\ ${ }^{2}$ Department of Pathology, Evanston Northwestern Healthcare, Evanston, Illinois \\ ${ }^{3}$ Evanston Northwestern Healthcare Research Institute, Evanston, Illinois \\ ${ }^{4}$ Department of Urology, Comprehensive Cancer Center, University of Michigan, Ann Arbor, Michigan \\ ${ }^{5}$ Comprehensive Cancer Center, University of Michigan, Ann Arbor, Michigan \\ ${ }^{6}$ Department of Urology, Northwestern University Medical School, Chicago, Illinois
}

\begin{abstract}
BACKGROUND. The underlying mechanisms permitting prostate cancer bone metastasis are poorly understood. We previously showed that the highly metastatic prostate cancer cell line, PC-3, inhibits bone marrow endothelial (HBME-1) cell growth in collagen gels and induces them to differentiate into cords, resembling angiogenesis in vivo.

METHODS. cDNA microarray analysis was performed to identify cytokines responsible for the effects of PC-3 cells on HBME-1 cells. Cytokine and neutralizing antibody studies were done to further investigate specific angiogenic factors, such as transforming growth factor $\beta$ (TGF $\beta$ ). TGF $\beta$ RNA and protein were detected by real-time RT-PCR and enzyme-linked immunosorbent assay (ELISA) analysis to measure their production by prostate cancer cell lines. Conditioned media experiments using TGF $\beta$ neutralizing antibodies were used to analyze TGF $\beta$ activation by prostate cancer cells.

RESULTS. PC-3 conditioned media altered the expression of several TGF $\beta$-regulated or associated genes in HBME-1 cells. Low concentrations of TGF $\beta$ cytokines inhibited HBME- 1 cell growth to a similar level as PC-3 conditioned media and partially induced differentiation. Inhibitors and neutralizing antibodies directed against TGF $\beta$ isoforms and TGF $\beta$ receptor type 2 (TGF $\beta$ RII) reversed the growth inhibition of HBME-1 cells conferred by PC-3 conditioned media. Yet, only TGFßRII neutralizing antibodies significantly inhibited HBME-1 differentiation. Also, prostate cancer cell lines produced low levels of TGF $\beta$ RNA and protein, and were shown to activate serum-derived TGF $\beta$.

CONCLUSIONS. These results suggest that prostate cancer cells mediate growth inhibition and differentiation of bone marrow endothelial cells both through production and activation of
\end{abstract}

Abbreviations: FBS, fetal bovine serum; ANOVA, analysis of variance between groups; TGF $\beta$, transforming growth factor $\beta$; TGF $\beta$ RII, TGF $\beta$ receptor type 2; VEGF, vascular endothelial growth factor; FGFb, fibroblast growth factor basic; PDGF, platelet-derived growth factor; LAP, latency-associated peptide; Fc:sTGF $\beta$ RII, soluble TGF $\beta$ receptor 2 fusion construct; ELISA, enzyme-linked immunosorbent assay; $\beta_{2}-\mathrm{M}, \beta_{2}$-microglobulin; BMP, bone morphogenetic protein.

Grant sponsor: Department of Pathology at Evanston Hospital; Grant sponsor: NIH Prostate Spore Grant (to K.L.K.); Grant number: NIH/NCI P50-CA090386-03.
Grant sponsor: NIH Biotechnology Research Training Grant (to J.M.B.); Grant number: GM 08449-09.

Grant sponsor: U.S HHS PHS NIH/NCI SPORE Grant in Prostate Cancer (to J.A.M.); Grant number: 1P50CA69568.

*Correspondence to: Dr. Karen L. Kaul, MD, PhD, Department of Pathology, Evanston Hospital, 2650 Ridge Avenue, Evanston, IL 60201. E-mail: k-kaul@northwestern.edu

Received 7 July 2005; Accepted 15 September 2005

DOI 10.1002/pros.20370

Published online 21 December 2005 in Wiley InterScience (www.interscience.wiley.com). 
TGF $\beta$ as well as alteration of TGF $\beta$ RII-mediated signal transduction. This could contribute to the establishment and growth of bone metastases. Prostate 66:632-650,2006. (C) 2005 Wiley-Liss, Inc.

KEY WORDS: $\quad$ prostate cancer; endothelium; TGF ; angiogenesis; bone metastasis

\section{INTRODUCTION}

Prostate cancer preferentially metastasizes to the bone, causing high morbidity and often resulting in death [1-5]. About $80 \%$ of patients with advanced disease have skeletal metastasis [6]. For these patients treatment options are few and none are curative [7-9]. It is critical that we identify and understand the factors that promote bone metastasis in order to develop more effective diagnostic and therapeutic tools.

It has been postulated that bone marrow endothelial cells are the initial contact site for metastatic prostate cancer cells [10-12]. Lehr and Pienta [10] demonstrated that prostate cancer cells preferentially adhere to endothelial cells derived from the bone marrow compared to those from other sites. Both normal and malignant prostate epithelial cells have been shown to bind well to bone marrow endothelial cells in vitro, but only tumor cells are capable of invasion through basement membrane in response to bone marrow endothelial cells [13] or invasion through endothelial cell monolayers [11,14]. In order for metastatic prostate cancer cells to form sizable lesions in the bone, stimulation of angiogenesis is necessary to provide a blood supply to the growing tumor $[15,16]$.

Using a co-culture collagen gel system, we recently showed a strong bi-directional interaction between highly metastatic prostate cancer cells (PC-3) and bone marrow endothelial cells (HBME-1) [17]. HBME-1 cells stimulated proliferation and migration of PC-3 cells; and concurrently the prostate cancer cells inhibited HBME-1 cell growth and induced them to differentiate into highly organized cords, resembling capillary networks. PC-3 conditioned media had a similar effect on HBME-1 cell growth and morphology in collagen gels. In this study, we analyzed factors potentially responsible for the effects of PC-3 cells on HBME- 1 cells grown in collagen gels. The results presented here may yield further insights as to how prostate cancer cells metastasize to and grow in the bone.

\section{MATERIALS AND METHODS}

\section{Cell Culture}

PC-3, DU-145, and LNCaP cells were obtained from the American Type Culture Collection (Rockville, MD). HBME-1 cells were a generous gift of Dr. Kenneth J. Pienta (University of Michigan Comprehensive Cancer Center, Ann Arbor, MI). All cell lines were maintained and conditioned media was collected as described previously [17].

\section{cDNA Microarray Analysis}

HBME-1 cells growing in collagen gels [17] were exposed to conditioned media from PC-3 and LNCaP cells or normal growth media. After $48 \mathrm{hr}$, cells were harvested and total RNA was extracted using Trizol ${ }^{\mathbb{R}}$ Reagent (Invitrogen Corp., Carlsbad, CA). DNA was removed using DNA-Free ${ }^{\mathrm{TM}}$ (Ambion, Inc., Austin, TX) and RNA was further purified using the RNeasy Mini Kit (Qiagen, Valencia, CA). RNA quantity was determined using a spectrophotometer and RNA integrity was determined by agarose gel electrophoresis. Generation of labeled cDNA probes and hybridization to a $4.1 \mathrm{~K}$ Cancer Array were done at the University of Michigan cDNA Microarray Core Facility according to their standard protocols. Briefly, $\mathrm{Cy} 3$ and Cy5 fluorescently-labeled cDNA probes were generated using the CyScribe ${ }^{\mathrm{TM}}$ First-Strand cDNA Labeling Kit (Amersham Biosciences, Inc., Piscataway, NJ) followed by hybridization to target cDNAs on glass slides. Hybridized microarrays were scanned with the Axon GenePix 4000a Scanner (Molecular Devices Corp., Union City, CA). Raw data was exported as Excel files and then imported into the $\mathrm{R}$ statistical language. Each microarray was normalized using a rank-invariant normalization [18]. After normalization, missing data was imputed using a nearest neighbor's algorithm. The resulting data was log-transformed and then fit using the analysis of variance between groups (ANOVA) model. Differential expression was determined by calculating $99.9 \%$ confidence intervals using a semi-parametric bootstrap method. All genes listed in the "Results" and in the "Appendix" are considered statistically significant using this data analysis method.

\section{Cytokine and Neutralizing Antibody Experiments}

All cytokines (transforming growth factor $\beta$ (TGF $\beta) 1,2$, and 3) and all neutralizing antibodies [anti-TGF $\beta 1,2$, and 3; anti-TGF $\beta$ receptor type 2

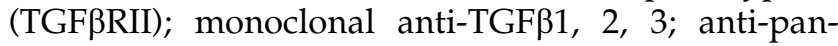
specific TGF $\beta$; anti-vascular endothelial growth factor (VEGF); anti-fibroblast growth factor basic (FGFb); and anti-platelet-derived growth factor (PDGF)] and latency-associated peptide (LAP) were purchased from R\&D Systems, Inc. (Minneapolis, MN). The soluble TGF $\beta$ receptor 2 fusion construct (Fc:sTGF $\beta$ RII) [19-21] 
was generously provided by Dr. Philip Gotwals (Biogen Idec, Inc., Cambridge, MA).

For cytokine studies, HBME-1 cells growing in collagen gels [17] were exposed to active TGF $\beta 1,2$, or 3 added directly to normal growth media. For neutralizing antibody studies, conditioned media experiments were performed as described previously [17]. HBME- 1 cells $\left(1 \times 10^{4}\right)$ were plated in 24-well plates in a single layer of collagen gel and fed either normal media or conditioned media plus or minus neutralizing antibodies (affinity-purified, if available). On day 6, HBME-1 cells were harvested and counted using a Z2 ${ }^{\mathrm{TM}}$ Coulter Counter ${ }^{\mathbb{R}}$ (Beckman Coulter, Inc., Fullerton, CA).

\section{Fluorescent Staining and Digital Microscopy}

Morphological changes induced in HBME-1 cells by prostate cancer cells were assessed using fluorescence staining and digital imaging microscopy. Collagen gel layers were fixed with $4 \%$ formaldehyde (Electron Microscopy Sciences, Fort Washington, PA) for $45 \mathrm{~min}$, followed by washes in phosphate-buffered saline. Gel layers were then stained with $1 \times \mathrm{SYBR}^{\mathrm{R}}$ Green I (BioWhittaker Molecular Applications, Rockland, ME) or a 1:5,000 dilution of a $1 \mathrm{mg} / \mathrm{ml}$ stock of Hoechst 33258 trihydrochloride (Sigma Chemical Co., St. Louis, $\mathrm{MO})$. Stained cells were imaged by digital fluorescent microscopy as described previously [17]. The number of nuclei per aggregate were counted.

\section{Analysis of TGF $\beta$ Expression by Prostate Cancer Cell Lines}

TGF $\beta$ expression was determined by real-time RTPCR and enzyme-linked immunosorbent assay (ELISA) analysis. The $\beta_{2}$-microglobulin $\left(\beta_{2}-\mathrm{M}\right)$ and TGF 32 Lightcycler ${ }^{\mathrm{TM}}$ RT-PCR assays (Roche Diagnostics Corp., Indianapolis, IN) were developed in our laboratory and the TGF $\beta 1$ assay was based on the work of Quan et al. [22]. Hybridization probes (fluorescence energy transfer probes for $\beta_{2}-\mathrm{M}$ and TGF $\beta 2$ and TaqMan ${ }^{\circledR}$ probes for TGF $\beta 1$ ) were used to determine mRNA expression. Values obtained for TGF $\beta 1$ and 2 mRNA expression were normalized to expression of $\beta_{2}-\mathrm{M}$. Cycle parameters were as follows: $\beta_{2}-\mathrm{M}=55^{\circ} \mathrm{C}$ for $10 \mathrm{~min} ; 95^{\circ} \mathrm{C}$ for $30 \mathrm{sec} ; 35$ cycles of $95^{\circ} \mathrm{C}$ for $10 \mathrm{sec}$, $62^{\circ} \mathrm{C}$ for $5 \mathrm{sec}$, and $72^{\circ} \mathrm{C}$ for $15 \mathrm{sec} ; 95^{\circ} \mathrm{C}$ for $2 \mathrm{~min}$; $60^{\circ} \mathrm{C}$ for $2 \mathrm{~min} ; 95^{\circ} \mathrm{C}$ for $0 \mathrm{sec}$; and $35^{\circ} \mathrm{C}$ for $0 \mathrm{sec}$. $\mathrm{TGF} \beta 1=50^{\circ} \mathrm{C}$ for $10 \mathrm{~min} ; 95^{\circ} \mathrm{C}$ for $3 \mathrm{~min} ; 50$ cycles of $95^{\circ} \mathrm{C}$ for $10 \mathrm{sec}, 66^{\circ} \mathrm{C}$ for $20 \mathrm{sec} ; 72^{\circ} \mathrm{C}$ for $15 \mathrm{sec}$; and $40^{\circ} \mathrm{C}$ for $0 \mathrm{sec}$. TGF $\beta 2=55^{\circ} \mathrm{C}$ for $10 \mathrm{~min} ; 95^{\circ} \mathrm{C}$ for $30 \mathrm{sec}$; 50 cycles of $95^{\circ} \mathrm{C}$ for $10 \mathrm{sec}, 53^{\circ} \mathrm{C}$ for $5 \mathrm{sec}$, and $72^{\circ} \mathrm{C}$ for $20 \mathrm{sec} ; 95^{\circ} \mathrm{C}$ for $2 \mathrm{~min} ; 60^{\circ} \mathrm{C}$ for $2 \mathrm{~min} ; 95^{\circ} \mathrm{C}$ for $0 \mathrm{sec}$; and $40^{\circ} \mathrm{C}$ for $0 \mathrm{sec}$. Primer and probe sequences are listed in Table I.
Production of TGF $\beta$ protein was measured by Quantikine ${ }^{\circledR}$ ELISA analysis (R\&D Systems) according to the manufacturer's instructions. Serum-containing conditioned media previously frozen at $-20^{\circ} \mathrm{C}$ was thawed and activated prior to assay in order to measure total (active + acid-activatable) TGF $\beta$ protein. Serumcontaining media was tested since HBME- 1 cells did not grow well in serum-free conditions. TGF $\beta$ production was measured in normal growth media as a background control, since $10 \%$ serum can contain up to $1,600 \mathrm{pg} / \mathrm{ml}$ TGF $\beta$ protein. To obtain protein concentrations, the normal media control value was subtracted from the values for each cell line, and then resulting values were normalized to the total number of cells at the time of conditioned media collection.

\section{TGF $\beta$ Activation by Prostate Cancer Cells}

TGF $\beta$ activation was assessed by comparing the effect on HBME-1 cell growth of serum-containing media conditioned by PC-3 cells to that of serum-free conditioned media to which serum was added after exposure to prostate cancer cells. Experiments were performed as described previously [17] with the addition of TGF $\beta$ neutralizing antibodies; and cells were harvested and counted.

\section{Statistical Analysis}

All numerical data is expressed as mean \pm standard deviation (when possible). Statistical analysis was conducted using ANOVA (Tukey's Multiple Comparison Post-Test), unless otherwise noted. A $P$-value $<$ 0.05 was considered statistically significant.

\section{RESULTS}

Our previous studies showed that prostate cancer cells (PC-3, DU-145, and LNCaP) and their conditioned media inhibited growth of HBME-1 cells in collagen gels [17]. For the more aggressive PC-3 cell line (and to a lesser extent, DU-145), the growth inhibition was accompanied by a strong induction of aggregation of cells into cord-like structures, resembling capillaries [17].

\section{Prostate Cancer Cell Conditioned Media Induces Signifıcant Gene Expression Changes of Several TGF $\beta$-Regulated and -Associated Genes}

As a screening tool to begin to identify the factors involved in the effects of the prostate cancer cells on HBME-1 cell growth and differentiation, cDNA microarray analysis was performed. Exposure of HBME-1 cells grown in collagen to PC-3 conditioned media for $48 \mathrm{hr}$ induced statistically significant changes in expression of hundreds of genes compared to growth 


\begin{tabular}{|c|c|c|}
\hline Gene & Primer sequences & Probe sequences \\
\hline \multirow[t]{2}{*}{$\begin{array}{l}\beta_{2}-\text { Microglobulin } \\
\quad\left(\beta_{2}-\mathrm{M}\right)\end{array}$} & Fwd: 5'-CTTGTCTTTCAGCAAGGACTG-3' & $\begin{array}{l}\text { 5'-ACATGGTTCACACGGCAGGCA /6- } \\
\text { FAM } /-3^{\prime}\end{array}$ \\
\hline & Rev: 5'-CCTCCATGATGCTGCTTACAT-3' & $\begin{array}{l}\text { 5'-5Cy5.5/ACTCATCTTTTT- } \\
\text { CAGTGGGGGTGA/3Phos/-3' }\end{array}$ \\
\hline $\begin{array}{l}\text { Transforming growth } \\
\text { factor } \beta \text { (TGF } \beta) 1[22]\end{array}$ & $\begin{array}{l}\text { Fwd: 5'-TGACAAGTTCAAGCAGAGTACA- } \\
\text { CACA-3' } \\
\text { Rev: 5'-AGAGCAACACGGGTTCAGGTA-3' }\end{array}$ & $\begin{array}{l}\text { 5' /6-FAM/TCAACACATCAGAGCTCC- } \\
\text { GAGAAGCG/TAMRA/-3' }\end{array}$ \\
\hline TGF $\beta 2$ & $\begin{array}{l}\text { Fwd: 5'-GAAGAAGCGTGCTTT-3' } \\
\text { Rev: 5'-TTTGCCAATGTAGTAGAG-3' }\end{array}$ & $\begin{array}{l}\text { 5'-TGAGTGTCTGAACTCCAT/6-FAM/-3' } \\
\text { 5'-/5Cy5.5/AATACGGGCATGCTCCAG/ } \\
\text { SpC3/-3' }\end{array}$ \\
\hline
\end{tabular}

in normal media, while LNCaP conditioned media affected expression of only a few genes. A complete list of affected genes showing statistically significant up-or down-regulation by PC-3 conditioned media is shown in the "Appendix."

The cDNA microarray analysis revealed several of the genes with altered expression are regulated by or associated with TGF $\beta$ signaling (Table II). Although none of the expression changes were greater than twofold, the interwoven loop design used for microarray analysis as well as the careful normalization across arrays and data analysis eliminated false signals. Many of the altered TGF $\beta$-regulated and -associated genes include factors involved in cell proliferation (activated p21/cdc42 Hs kinase, cell division cycle 25C and cyclindependent kinase 6), cell adhesion (integrins, laminins, and fibronectin), invasion (tissue inhibitor of metalloproteinase 2), and angiogenesis (Rho GTPase activating protein 5 and TGF 33 ). Based on these results, we decided to analyze the role of TGF $\beta$, in addition to other cytokines, in the regulation of HBME-1 cell growth and differentiation conferred by PC-3 conditioned media.

\section{TGF $\beta$ Cytokines at Low Concentrations Inhibit Growth of HBME-I to a Similar Level as Prostate Cancer Conditioned Media and Induce Aggregate Formation}

Active TGF $\beta 1,2$, and 3 cytokines at various concentrations from $1 \mathrm{pg} / \mathrm{ml}$ to $10 \mathrm{ng} / \mathrm{ml}(0.04-$ $400 \mathrm{pM}$ ) were added to HBME-1 cells to determine their effects on cell proliferation and morphology. All three TGF $\beta$ isoforms inhibited growth of HBME-1 cells in a dose-dependent manner with TGF $\beta 1$ being most potent. At high concentrations [1-10 ng/ml (40$400 \mathrm{pM}$ )] each TGF $\beta$ isoform inhibited cell proliferation by more than $80 \%$ (Fig. 1). At more physiologically relevant concentrations $[10-100 \mathrm{pg} / \mathrm{ml}(0.4-4 \mathrm{pM})]$, the TGF $\beta$ isoforms inhibited HBME- 1 cell growth similarly to PC-3 conditioned media (by $\sim 30 \%$ ). Also, low concentrations of active TGF $\beta 1$ induced HBME-1 cells to form cords, resembling angiogenesis (Table III). Maximal aggregate size, as measured by the number of nuclei per aggregate, was achieved at a concentration of $5 \mathrm{pg} / \mathrm{ml}(0.2 \mathrm{pM})$ TGF $\beta 1$, yet these aggregates were smaller than the aggregates formed in the presence of PC -3 conditioned media. The reduced effect may be a result of suboptimal TGF $\beta$ concentration or the need for a cooperative effect with other cytokines. Low concentrations ( $\mathrm{pg} / \mathrm{ml}$ range) of active TGF $\beta 2$ and 3 cytokines also induced aggregate formation (data not shown), suggesting redundancy of action for TGF $\beta$ isoforms in vitro.

\section{TGF $\beta$ Neutralizing Antibodies Reverse the Growth Inhibition of HBME-I Cells Induced by Prostate Cancer Cell Conditioned Media}

To further determine the mediator(s) of the effects of PC-3 cells on HBME- 1 cell growth and differentiation, neutralizing antibodies were used to target various angiogenesis inducers, including TGF $\beta$, VEGF, FGFb, and PDGF. HBME-1 cells were grown in serumcontaining media, since they did not grow well in serum-free conditions. Thus, any inhibitor tested could also inhibit factors present in the serum. Only antibodies/inhibitors directed against TGF $\beta$ signaling reversed HBME-1 growth inhibition conferred by PC3 conditioned media (Table IV). Blockage of multiple TGF $\beta$ isoforms resulted in even higher proliferation than the normal media control, suggesting serumderived TGF $\beta$ was being inhibited. Neutralizing antibodies to VEGF and PDGF had little or no effect on cell growth and anti-FGFb caused further growth 
TABLE II. Significant Gene Expression Changes in HBME-I Cells Induced by PC-3 Conditioned Media (TGF $\beta$-Regulated and Associated Genes)

\begin{tabular}{|c|c|c|}
\hline Gene & Accession number & Fold change \\
\hline \multicolumn{3}{|l|}{ Increased } \\
\hline Laminin, alpha 3 & AA001432 & 1.24 \\
\hline Fibronectin 1 & R62612 & 1.20 \\
\hline Tissue inhibitor of metalloproteinase 2 & AA486280 & 1.16 \\
\hline Plasminogen activator inhibitor 1 mRNA-binding protein & AA487070 & 1.16 \\
\hline Activated p21/cell division cycle 42 Hs kinase & AA427891 & 1.15 \\
\hline Janus kinase 2 & AA284634 & 1.15 \\
\hline Cyclin-dependent kinase 6 & H73724 & 1.14 \\
\hline Platelet-derived growth factor (PDGF) beta polypeptide & T49539 & 1.10 \\
\hline \multicolumn{3}{|l|}{ Decreased } \\
\hline Rho GTPase activating protein 5 & W86145 & 1.48 \\
\hline Latent transforming growth factor $\beta$ binding protein 2 & AA424629 & 1.42 \\
\hline Integrin, alpha 9 & AA865557 & 1.24 \\
\hline Transforming growth factor $\beta 3$ & N76883 & 1.22 \\
\hline Cell division cycle $25 \mathrm{C}$ & W95001 & 1.22 \\
\hline Jun D proto-oncogene & N66278 & 1.19 \\
\hline Bone morphogenetic protein 7 & W73473 & 1.19 \\
\hline Activin A receptor, type II & AA682819 & 1.18 \\
\hline Laminin, gamma 2 & AA677534 & 1.17 \\
\hline Forkheadbox J2 & AA902249 & 1.15 \\
\hline Integrin, beta 8 & R74357 & 1.15 \\
\hline p21/cell division cycle 42/Rac1-activated kinase 1 & AA173411 & 1.15 \\
\hline
\end{tabular}

cDNA microarray data was normalized across arrays, log-transformed, and then fit using the analysis of variance between groups (ANOVA) model. A semi-parametric bootstrap method using 99.9\% confidence intervals was used to determine differential expression. Expression changes for all genes listed were deemed significant (see "Materials and Methods").

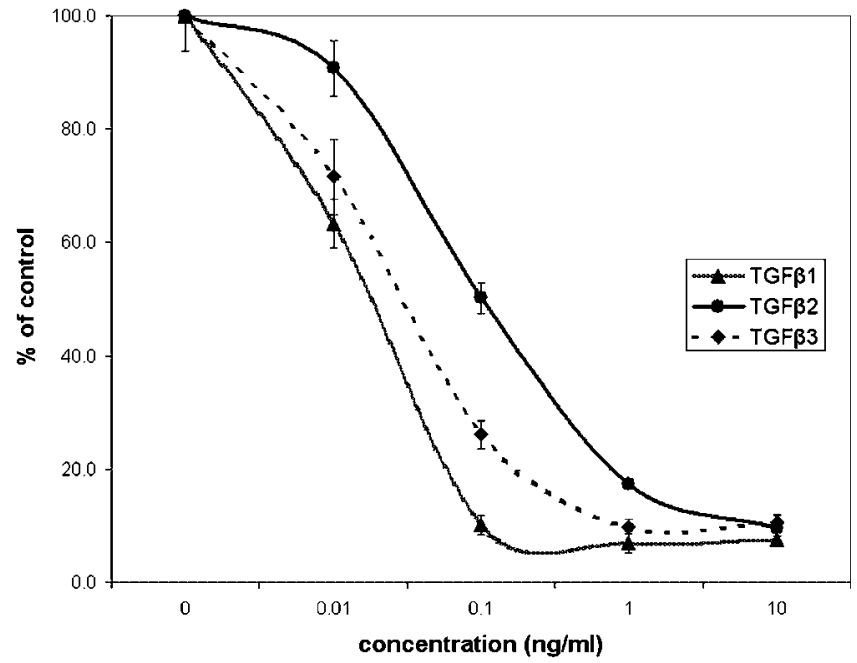

Fig. I. Effect of transforming growth factor $\beta$ (TGF $\beta$ ) cytokines on HBME-I cell growth. HBME-I cells growing in collagen gels were subjected to activeTGF $\beta$ I, 2 , or 3 cytokines at concentrations of 0.0 , $0 . \mathrm{I}, \mathrm{I}$, and $10 \mathrm{ng} / \mathrm{ml}$. After 6 days, cells were harvested and counted using a Z2 ${ }^{\text {TM }}$ Coulter Counter ${ }^{\mathrm{R}}$. EachTGF $\beta$ isoform inhibited growth in a dose-dependent manner. Low concentrations of TGF $\beta$ cytokines best mimicked the effects of prostate cancer cells on HBME-I cells. Individual data points are means of total number of cells and standard deviations are represented by error bars; and results are presented as the average of two experiments for each cytokine tested. inhibition. This strongly suggests primarily TGF $\beta$ mediates the growth inhibition of HBME-1 cells by prostate cancer cells.

\section{Anti-TGF $\beta R$ II Neutralizing Antibodies Inhibit HBME-I Cord Formation Induced by Prostate Cancer Cell Conditioned Media}

In addition to their effect on cell proliferation, the neutralizing antibodies and inhibitors to various angiogenic factors were tested for their ability to block HBME-1 cell differentiation induced by PC-3 conditioned media. Only anti-TGFßRII neutralizing antibodies $(2 \mu \mathrm{g} / \mathrm{ml})$ inhibited cord formation (Fig. 2), reducing it by about $50 \%$. None of the other neutralizing antibodies inhibited HBME-1 cord formation (data not shown), including inhibitors of TGF $\beta$ (Table V). This suggests that signaling through TGF $\beta$ RII plays an important role in angiogenesis.

In contrast to the inhibition of cords by anti-TGF $\beta$ RII antibodies, inhibitors targeting multiple TGF $\beta$ isoforms actually induced formation of larger and more multicellular aggregates than PC-3 conditioned media alone (Table V). These TGF $\beta$ inhibitors include antipan-specific TGF $\beta$, monoclonal anti-TGF $\beta 1,2$, 3, Fc:sTGF $\beta$ RII, and LAP. Each of these inhibitors blocks 
TABLE III. Size of HBME-I Aggregates Induced by TGF $\beta$ I Cytokine

\begin{tabular}{|c|c|c|}
\hline Condition & $\begin{array}{l}\text { Mean no. of nuclei } \\
\text { per aggregate } \\
\quad(n=5)^{\mathrm{a}}\end{array}$ & $P$-value ${ }^{\mathrm{b}}$ \\
\hline Normal media & $37.2 \pm 7.4$ & NA \\
\hline PC -3 conditioned media & $320.0 \pm 65.3$ & $<0.01$ \\
\hline Normal media + vehicle & $27.2 \pm 7.5$ & N.S. \\
\hline \multicolumn{3}{|l|}{$\begin{array}{l}\text { Normal media }+X \text { ng/ml } \\
\quad \text { TGF } \beta 1\end{array}$} \\
\hline+0.001 & $41.4 \pm 3.1$ & N.S. \\
\hline+0.005 & $95.6 \pm 54.6$ & $<0.01$ \\
\hline+0.01 & $58.5 \pm 25.2$ & N.S. \\
\hline+0.02 & $38.2 \pm 28.6$ & N.S. \\
\hline+0.1 & $16.5 \pm 6.6$ & N.S. \\
\hline+1.0 & $16.2 \pm 5.7$ & N.S. \\
\hline+10 & $17.6 \pm 7.0$ & N.S. \\
\hline
\end{tabular}

N.S., not statistically significant.

${ }^{a}$ Means of total number of nuclei per aggregate \pm standard deviation.

${ }^{\mathrm{b}}$ Versus normal media control.

more than one TGF $\beta$ isoform, including TGF $\beta 1$. For instance, LAP is associated with multiple TGF $\beta$ isoforms in vivo and is partly responsible for maintaining TGF $\beta$ in a latent state. Thus, LAP is a potent inhibitor of TGF $\beta$, and so the low concentrations used were sufficient to cause a similar effect as the other TGF $\beta$ inhibitors. The increased cord formation due to inhibi- tion of multiple TGF $\beta$ isoforms was also significant compared to an additional control in which twice the number of HBME-1 cells was seeded initially and then grown in the presence of PC-3 conditioned media. This suggests that the presence of more cells is not solely responsible for increased cord formation. However, this does not rule out the possibility that a higher proliferation rate may play a role in the increased cord formation due to inhibition of multiple TGF $\beta$ isoforms. The difference in effect for anti-TGF $\beta$ RII antibodies and inhibitors of TGF $\beta$ isoforms may be attributable to the way in which TGF $\beta$ signaling is disrupted in each case and also due to TGF $\beta$ superfamily receptor/ligand promiscuity.

\section{TGF $\beta$ mRNA and Protein Expression by Prostate Cancer Cells}

We measured TGF $\beta 1$ and 2 mRNA and protein expression in PC-3, DU-145, and LNCaP cells by realtime RT-PCR and Quantikine ${ }^{\circledR}$ ELISA analysis. As shown in Table VI, PC-3 and DU-145 cells expressed TGF $\beta 1$ mRNA, while LNCaP cells did not. All three cell lines produced TGF $\beta 2$ mRNA. ELISA analysis of serum-containing conditioned media revealed TGF $\beta 1$ protein in PC-3 and DU-145 conditioned media (36 pg and 17 pg per $1 \times 10^{5}$ cells, respectively), but none above that normally present in serum-containing media was found in LNCaP conditioned media (Table VI). However, only PC-3 conditioned media contained TGF $\beta 2$ protein ( 48 pg per $1 \times 10^{5}$ cells). In

TABLE IV. Effect of Various Neutralizing Antibodies and SpecifıcTGF $\beta$ Inhibitors on HBME-I Cell Growth in Collagen in the Presence of PC-3 Conditioned Media

\begin{tabular}{|c|c|c|c|}
\hline Condition & $\%$ of control ${ }^{\mathrm{a}}$ & $\begin{array}{c}\% \text { change versus } \\
\text { normal media ( } P \text {-value })\end{array}$ & $\begin{array}{c}\% \text { change versus PC-3 } \\
\text { conditioned media ( } P \text {-value })\end{array}$ \\
\hline Normal media & $100.0 \pm 8.4$ & NA & $40.3 \uparrow(<0.001)$ \\
\hline PC -3 conditioned media & $71.3 \pm 6.6$ & $28.7 \downarrow(<0.001)$ & NA \\
\hline$+10 \mu \mathrm{g} / \mathrm{ml}$ anti-TGF $\beta 1$ & $94.4 \pm 10.2$ & $5.6 \downarrow$ (N.S.) & $32.4 \uparrow(<0.001)$ \\
\hline$+10 \mu \mathrm{g} / \mathrm{ml}$ anti-TGF $\beta 2$ & $103.8 \pm 6.1$ & $3.8 \uparrow($ N.S. $)$ & $45.6 \uparrow(<0.001)$ \\
\hline$+10 \mu \mathrm{g} / \mathrm{ml}$ anti-TGF $\beta 3$ & $102.9 \pm 8.0$ & $2.9 \uparrow($ N.S.) & $44.3 \uparrow(0.001)$ \\
\hline$+20 \mu \mathrm{g} / \mathrm{ml}$ anti-TGF $\beta R 2$ & $88.6 \pm 2.9$ & $11.4 \downarrow(<0.001)$ & $24.3 \uparrow(<0.005)$ \\
\hline$+50 \mu \mathrm{g} / \mathrm{ml}$ anti-pan-specific TGF $\beta$ & $117.9 \pm 3.2$ & $17.9 \uparrow(<0.001)$ & $65.4 \uparrow(<0.001)$ \\
\hline$+10 \mu \mathrm{g} / \mathrm{ml}$ monoclonal anti-TGF $\beta 1,2,3$ & $135.0 \pm 10.0$ & $35.0 \uparrow(<0.001)$ & $89.4 \uparrow(<0.001)$ \\
\hline$+1 \mu \mathrm{g} / \mathrm{ml} \mathrm{LAP}$ & $128.0 \pm 19.3$ & $28.0 \uparrow(<0.05)$ & $79.6 \uparrow(<0.001)$ \\
\hline$+10 \mu \mathrm{g} / \mathrm{ml}$ Fc:sTGF $\beta R 2$ & $120.6 \pm 11.3$ & $20.6 \uparrow(<0.01)$ & $69.1 \uparrow(<0.001)$ \\
\hline$+10 \mu \mathrm{g} / \mathrm{ml}$ anti-VEGF & $72.4 \pm 7.4$ & $27.7 \downarrow(<0.001)$ & $1.5 \uparrow($ N.S.) \\
\hline$+10 \mu \mathrm{g} / \mathrm{ml}$ anti-FGFb & $53.8 \pm 11.6$ & $46.2 \downarrow(<0.001)$ & $24.5 \downarrow(<0.001)$ \\
\hline$+50 \mu \mathrm{g} / \mathrm{ml}$ anti-PDGF & $62.0 \pm 3.0$ & $38.0 \downarrow(<0.001)$ & $13.0 \downarrow(<0.05)$ \\
\hline $2 \times$ no. of HBME- 1 cells & $105.6 \pm 5.2$ & $5.6 \uparrow(<0.5)$ & $48.2 \uparrow(<0.001)$ \\
\hline
\end{tabular}

Data normalized to control antibodies for each condition and to normal media control.

N.S., not statistically significant.

${ }^{a}$ Represented as mean percentage compared to normal media control \pm standard deviation. 


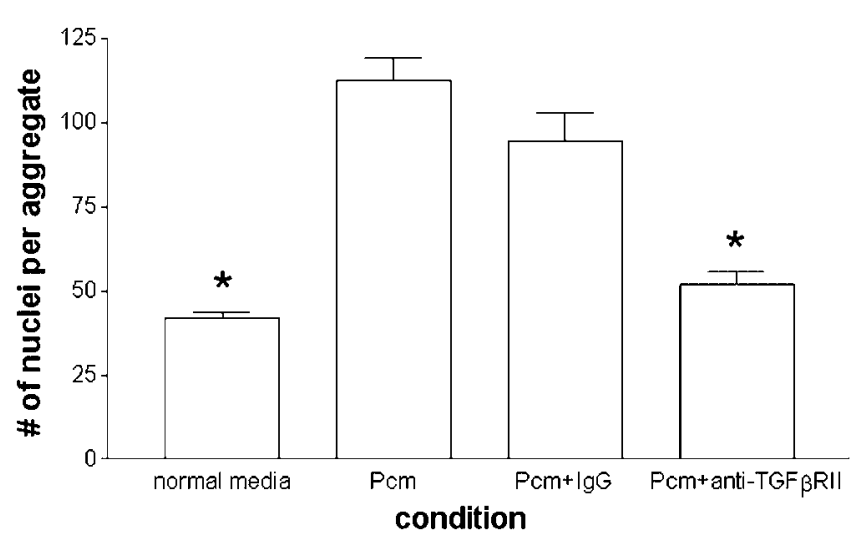

Fig. 2. Anti-TGF $\beta$ receptor type 2 (TGF $\beta$ RII) antibodies block HBME-I cord formation induced by PC-3 conditioned media (Pcm). Anti-TGF $\beta$ RII neutralizing antibodies $(2 \mu \mathrm{g} / \mathrm{ml})$ were tested for their ability to prevent formation of cords by HBME-I cells grown in collagen in the presence of PC-3 conditioned media. After 6 days, cells were fixed with $4 \%$ formaldehyde, stained with SYBR ${ }^{\mathbb{R}}$ Green I, and nuclei were counted in cord-like aggregates for each condition. The values are means of total number of nuclei per aggregate (largest five aggregates per condition) and error bars represent standard deviations. Results are presented as the average of two experiments. Significant values compared to PC-3 conditioned media are represented by a* symbol.

comparison, HBME-1 conditioned media contained both TGF $\beta$ isoforms ( $28 \mathrm{pg}$ TGF $\beta 1$ and $49 \mathrm{pg}$ TGF $\beta 2$ per $1 \times 10^{5}$ cells). Overall, the amount of TGF $\beta$ detected in the prostate cancer conditioned medias was low, suggesting that prostate cancer cells mediate some of their effects by activating TGF $\beta$ in the serum.

\section{Activation of Serum-Derived TGF $\beta$ by Prostate Cancer Cells Contribute toTheir Growth-Inhibitory Effect on HBME-I Cells}

Since TGF $\beta$ protein levels were low in the prostate cancer cell conditioned medias, we compared growth of HBME-1 cells in prostate cancer cell conditioned media collected in two different ways to determine if activation of TGF $\beta$ in the serum was the reason for growth inhibition of HBME-1 cells. As shown in Figure 3, when prostate cancer cells conditioned serum-free media to which serum was added just prior to use on HBME-1 cells, a reduced effect on HBME-1 cell growth was observed (in comparison to conditioned media prepared containing serum that was exposed to the prostate cancer cells). The addition of anti-pan-specific TGF $\beta$ antibodies to serum-containing PC-3 conditioned media reversed the growth inhibition normally observed, suggesting that TGF $\beta$ was responsible for the growth inhibition of HBME-1 cells by serum-containing PC-3 conditioned media (Fig. 3). Thus, exposure of serum-derived TGF $\beta$ to prostate cancer cells is necessary for the full effect of their conditioned media on HBME-1 cells.

\section{DISCUSSION}

Our previous results indicate that prostate cancer cells secrete factors that affect growth and differentiation of bone marrow endothelial cells grown in collagen gels [17]. In this study, we demonstrated that TGF $\beta$ production and activation by prostate cancer cells and signaling through TGFßRII in HBME-1 cells mediate

TABLE V. Effect of TGF $\beta$ Antibodies and Inhibitors on Size and Number of HBME-I Aggregates Formed in the Presence of PC-3 Conditioned Media

\begin{tabular}{|c|c|c|c|c|}
\hline Condition & Mean & $\begin{array}{c}\text { Fold change versus } \\
\text { PC-3 conditioned } \\
\text { media }(P \text {-value })\end{array}$ & Mean & $\begin{array}{l}\text { Fold change versus } \\
\text { PC-3 conditioned } \\
\text { media ( } P \text {-value })\end{array}$ \\
\hline Normal media & $58 \pm 22$ & $0.39(<0.0001)$ & $4.5 \pm 1.9$ & $0.31(<0.0005)$ \\
\hline PC-3 conditioned media & $147 \pm 53$ & NA & $14.8 \pm 5.0$ & NA \\
\hline$+10 \mu \mathrm{g} / \mathrm{ml}$ mouse IgG1 & $111 \pm 38$ & $0.75(<0.05)$ & $14.5 \pm 7.0$ & 0.98 (N.S.) \\
\hline$+10 \mu \mathrm{g} / \mathrm{ml}$ monoclonal anti-TGF $\beta 1,2,3$ & $179 \pm 55$ & 1.22 (N.S.) & $158.3 \pm 149$ & 10.73 (N.S. $^{\mathrm{a}}$ ) \\
\hline$+10 \mu \mathrm{g} / \mathrm{ml}$ mouse IgG2a & $126 \pm 36$ & 0.86 (N.S.) & $24.0 \pm 6.2$ & $1.63(<0.05)$ \\
\hline$+10 \mu \mathrm{g} / \mathrm{ml}$ Fc:sTGF $\beta$ RII & $226 \pm 70$ & $1.54(<0.0005)$ & $100.8 \pm 30$ & $6.83(<0.01)$ \\
\hline$+1 \mu \mathrm{g} / \mathrm{ml} \mathrm{LAP}$ & $244 \pm 80$ & $1.67(<0.005)$ & $169.0 \pm 56$ & $11.46(<0.01)$ \\
\hline
\end{tabular}

The Student's $T$-test was used to determine statistical significance $(P$-value $<0.05)$.

N.S., not significant.

${ }^{\text {a }} P$-value is $<0.001$ using ANOVA to determine statistical significance. 
TABLE VI. TGF $\beta$ mRNA and Protein Production by Prostate Cancer Cells and HBME-I Cells

\begin{tabular}{|c|c|c|c|c|}
\hline \multirow[b]{2}{*}{ Cell line } & \multicolumn{2}{|c|}{ mRNA expression (normalized ${ }^{\mathrm{a}} \mathrm{C}_{\mathrm{T}}$ value) } & \multicolumn{2}{|c|}{$\begin{array}{l}\text { Protein levels in conditioned media } \\
\text { pg per } 10^{5} \text { cells } / \mathbf{p M}(P \text {-value })^{\mathrm{b}}\end{array}$} \\
\hline & TGF $\beta 1$ & TGF $\beta 2$ & TGF $\beta 1$ & TGF $\beta 2$ \\
\hline PC-3 & 22.06 & 27.04 & $35.85 / 6.05(<0.0005)$ & $48.10 / 8.1(<0.005)$ \\
\hline DU-145 & 20.82 & 30.19 & $17.05 / 4.5(<0.05)$ & $0^{c}$ \\
\hline LNCaP & Negligible & 33.22 & $0^{c}$ & $0^{\mathrm{c}}$ \\
\hline HBME-1 & N.D. & N.D. & $28.47 / 9.0(<0.01)$ & $49.05 / 15.5(<0.0001)$ \\
\hline
\end{tabular}

N.D., not determined.

For comparison of RNA expression, lower normalized $\mathrm{C}_{\mathrm{T}}$ values represent higher relative expression levels compared with other cell lines. To obtain the protein concentrations for each cell line, the normal media control values were first subtracted out and then resulting values were normalized to the total number of cells at collection of conditioned media.

${ }^{a}$ Normalized to $\beta_{2}-\mathrm{M} \mathrm{C}$ value for each cell line.

${ }^{\mathrm{b}}$ Statistically significant compared to normal media control $(P$-value $<0.05)$.

${ }^{\mathrm{C}}$ Any TGF $\beta 1$ or 2 protein measured was below baseline levels in the normal media control.

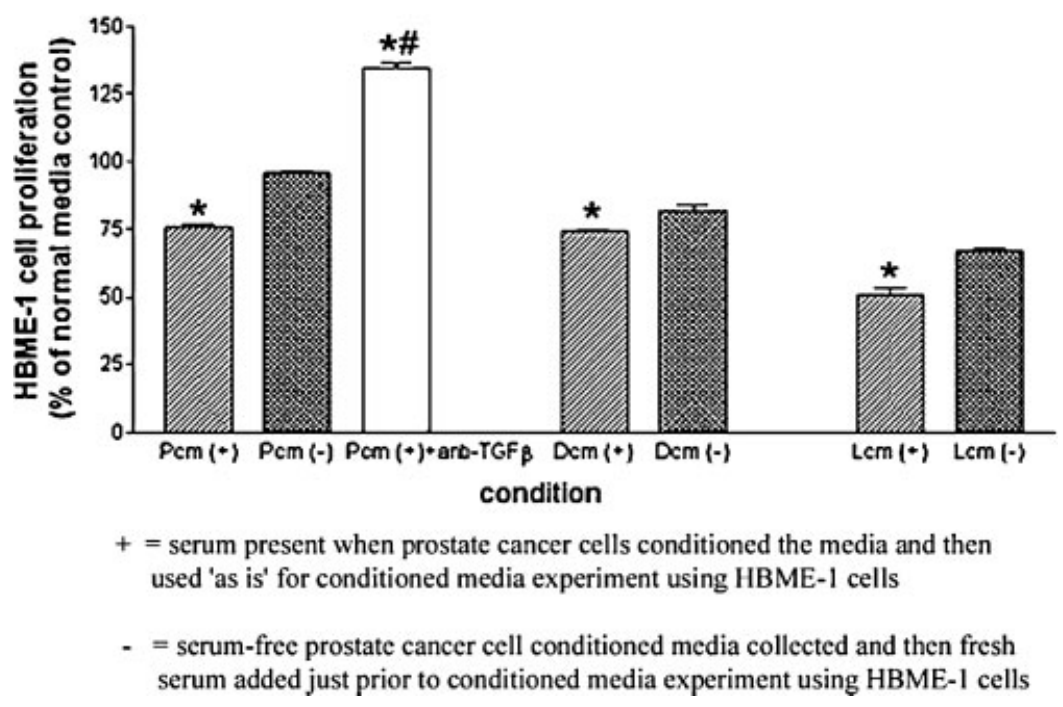

Fig. 3. Activation of serum-derived TGF $\beta$ by prostate cancer cell lines. A comparison of growth was made for HBME-I cells exposed to serum-containing prostate cancer cell conditioned media versus serum-free conditioned media to which serum was later added. Conditioned media experiments were performed as described in the "Materials and Methods." For PC-3 conditioned media, a comparison was also made to HBME-I cells exposed to serum-containing conditioned media plus the addition of anti-pan-specificTGF $\beta$ antibody. Data is normalized to normal media controls (normal media with serum and serum-free normal media plus serum later). Normalized mean values are expressed as percentage of control and error bars represent standard deviations. For each prostate cancer cell line, there is a reduced effect on HBME- I cell growth when serum-free conditioned media is used. Values with statistically significant differences compared with the serum-free condition for each cell line are denoted with a *symbol. Anti-pan-specificTGF $\beta$ antibody completely reversed the growth inhibition conferred by serum-containing PC-3 conditioned media and significance $(P$-value $<0.05)$ is denoted with a ${ }^{\#}$ symbol.

growth and differentiation of HBME-1 cells. TGF $\beta$ isoforms are involved in several cellular responses, including growth inhibition and regulation of angiogenesis [23]. In addition, TGF $\beta$ is thought to have a dual role in prostate cancer progression, involving inhibition of tumor growth early, but stimulation of progression in later stages [23-26]. This study provides further insight into the role TGF $\beta$ signaling plays in prostate cancer bone metastasis.
Microarray analysis revealed that PC-3 conditioned media altered expression of several TGF $\beta$-regulated and -associated genes in HBME-1 cells. Consequently, we did functional studies to determine the role of TGF $\beta$, and other angiogenic factors, in the effects of PC-3 conditioned media on HBME-1 cell growth and differentiation in collagen gels. TGF $\beta$ cytokine studies and neutralizing antibody experiments demonstrated that TGF $\beta$ is primarily responsible for the growth 
inhibition of HBME-1 cells by PC-3 conditioned media. TGF $\beta$ cytokine experiments clearly showed that HBME-1 cells are strongly inhibited by active recombinant TGF $\beta$. Additionally, of all the neutralizing antibodies tested, only antibodies targeting TGF $\beta$ signaling reversed HBME-1 growth inhibition caused by PC-3 conditioned media. An interesting finding was that blocking multiple TGF $\beta$ isoforms yielded even higher cell proliferation than the normal media control, suggesting that serum-derived TGF $\beta$ was being inhibited. Another factor that may be important is FGFb, since neutralizing antibodies also caused growth inhibition of HBME-1 cells.

TGF $\beta$ and its type II receptor are key regulators of HBME-1 cell differentiation. Low concentrations of TGF $\beta$ cytokines induced HBME- 1 to differentiate to form cords in collagen gel cultures, resembling angiogenesis. Although the effect was lower than with PC-3 conditioned media, it does indicate that TGF $\beta$ plays a key role in HBME-1 cord formation (differentiation). The growth inhibition conferred by low concentrations of TGF $\beta$ may prime the bone marrow endothelial cells to undergo differentiation, being an initiating step of angiogenesis [27].

Of all the inhibitors tested, only anti-TGF $\beta$ RII neutralizing antibodies inhibited differentiation of HBME-1 cells in the presence of PC-3 conditioned media. No other antibodies significantly inhibited cord formation, including several direct inhibitors of TGF $\beta$ isoforms. It is possible that a higher concentration of inhibitors is required to block HBME-1 differentiation. Also, our list of inhibitors was not comprehensive, so other angiogenic factors may be involved. Regardless, inhibition of TGF $\beta$ RII appears to be a potent means of blocking HBME-1 differentiation induced by PC-3 conditioned media.

It is unclear why there were such different results for blockage with anti-TGF $\beta$ RII antibodies compared to use of TGF $\beta$ antibodies and inhibitors. One possible cause may be anti-TGF $\beta$ RII antibodies completely block all signaling through the TGFßRII receptor in HBME-1 cells, but inhibitors of TGF $\beta$ isoforms may not completely block receptor signaling.

Another possibility for the difference in blocking with anti-TGF $\beta$ RII antibodies versus direct inhibition of TGF $\beta$ isoforms is the potential ability of TGF $\beta$ to signal through other receptors and/or the ability of other ligands to bind and signal through TGF $\beta$ RII. TGF $\beta$ s are members of a large superfamily of cell growth and differentiation mediators, which includes activins, inhibins, bone morphogenetic proteins (BMPs), and the Müllerian inhibitory substance [24,26]; and there is evidence of promiscuity among the various ligands and receptors of this superfamily $[28,29]$. For instance, activin receptor-like kinase 2, a type I receptor, has been shown in vitro to bind activin [30] as well as BMP2 and 4 [31,32]; and its mouse homolog has been shown to bind TGF $\beta$ when overexpressed [33]. A better understanding is needed as to how TGF $\beta$ and its related family members mediate cell signaling, including their overlapping receptor usage and downstream activities.

It was surprising that inhibition of multiple TGF $\beta$ isoforms using anti-pan-specific TGF $\beta$, monoclonal anti-TGF $\beta 1$, 2, 3, Fc:sTGF $\beta$ RII, and LAP resulted in a dramatic increase in the size and number of cords. TGF $\beta$ is generally considered an angiogenesis inducer $[16,34,35]$, yet there is also evidence that blocking TGF $\beta$ signaling can induce angiogenesis and/or a more aggressive phenotype [36-38]. The concentrations of TGF $\beta$ inhibitors used may not have completely blocked TGF $\beta$ activity. Thus, low concentrations of TGF $\beta$ may have induced further cell differentiation. In addition, factors other than TGF $\beta$ may be present in the PC-3 conditioned media that also induce HBME-1 cells to differentiate. Further analysis is needed to understand the role of TGF $\beta$ signaling in prostate cancer-induced bone marrow endothelial cell differentiation.

Our findings also suggest that activation, not simply production, of TGF $\beta$ by prostate cancer cells is important for their effects on HBME-1 cells grown in collagen gels. Activation of TGF $\beta$ in serum in vitro may correlate to an extent the activation of latent TGF $\beta$ in the bone. Large quantities of latent TGF $\beta$ are stored within the bone and activation of just a small portion of TGF $\beta$ is enough to mediate cell growth and differentiation $[39,40]$. Prostate cancer cells may activate latent TGF $\beta$ in the bone either directly as suggested by our studies or through its secreted proteases [40-42], leading to stimulation of angiogenesis to promote metastatic growth [34].

Further studies are needed to analyze the mechanisms by which TGF $\beta$ and other growth factors work together to regulate bone marrow endothelial cell growth and angiogenesis. To begin to identify other angiogenic factors besides TGF $\beta$ that can also induce angiogenesis in bone marrow endothelial cells, we are utilizing cytokine arrays to identify other proteins secreted by prostate cancer cells that are capable of inducing angiogenesis in HBME-1 cells. Revealing these factors and understanding their role, along with TGF $\beta$ and TGF $\beta$ RII, in prostate cancer cell-induced angiogenesis should lead to more effective antiangiogenic treatments for metastatic prostate cancer.

\section{ACKNOWLEDGMENTS}

We thank Tracy Roberts for her assistance with imaging and Jing Lu for her help with statistical analysis. 


\section{APPENDIX: EFFECT OF PROSTATE CANCER CELL CONDITIONED MEDIA ON HBME-I GENE EXPRESSION IN COLLAGEN GELS}

See 'Materials and Methods'

\section{PC-3 Conditioned Media on HBME-I Cells}

\begin{tabular}{|c|c|c|}
\hline Gene & Accession number & Fold change \\
\hline \multicolumn{3}{|l|}{ Decreased expression } \\
\hline Potassium inwardly-rectifying channel, subfamily J, member 13 & H97186 & 1.78 \\
\hline Glutamate receptor, metabotropic 3 & N62328 & 1.75 \\
\hline Rho GTPase activating protein 5 & W86145 & 1.48 \\
\hline Ankylosis, progressive (mouse) homolog & AA007428 & 1.46 \\
\hline Kruppel-like factor 6 & AA055585 & 1.46 \\
\hline Xeroderma pigmentosum, complementation group A & AA453300 & 1.44 \\
\hline Hypothetical protein MGC15523 & AI016677 & 1.44 \\
\hline Hypothetical protein FLJ13941 & AA005329 & 1.44 \\
\hline Latent transforming growth factor beta binding protein 2 & AA424629 & 1.42 \\
\hline Ferrochelatase (protoporphyria) & AA025142 & 1.40 \\
\hline Tissue factor pathway inhibitor 2 & AA399473 & 1.38 \\
\hline Serine/threonine kinase 4 & T94961 & 1.37 \\
\hline Glutathione S-transferase M1 & AA290737 & 1.36 \\
\hline MT-protocadherin & AA707714 & 1.35 \\
\hline Hypothetical protein FLJ10890 & AA489394 & 1.35 \\
\hline Hypothetical protein DKFZp566I133 & N78263 & 1.32 \\
\hline FAT tumor suppressor (Drosophila) homolog 2 & H10939 & 1.32 \\
\hline Apolipoprotein C-IV & T71886 & 1.31 \\
\hline Hypothetical protein FLJ10648 & AA007402 & 1.31 \\
\hline Hypothetical protein MGC5347 & AA451905 & 1.31 \\
\hline ATP-binding cassette, sub-family G (WHITE), member 2 & W84773 & 1.30 \\
\hline CD83 antigen (activated B lymphocytes, immunoglobulin superfamily) & AA111969 & 1.30 \\
\hline Spectrin $\mathrm{SH} 3$ domain binding protein 1 & R16667 & 1.28 \\
\hline HIR (histone cell cycle regulation defective homolog A (S. cerevisiae) & W94880 & 1.28 \\
\hline Valosin-containing protein & AA489681 & 1.28 \\
\hline Annexin A8 & AA252968 & 1.28 \\
\hline Stromal cell-derived factor 1 & AA447115 & 1.28 \\
\hline FGFR1 oncogene partner & AA884755 & 1.27 \\
\hline Metallothionein 1E (functional) & R95882 & 1.27 \\
\hline Alcohol dehydrogenase 1B (class I), beta & AA682469 & 1.27 \\
\hline Kininogen & R89067 & 1.27 \\
\hline Galactosidase, alpha & AA251784 & 1.27 \\
\hline CDP-diacylglycerol synthase & R31562 & 1.27 \\
\hline Dead ringer (Drosophila)-like 1 & AA705382 & 1.26 \\
\hline Bromodomain adjacent to zinc finger domain, $2 \mathrm{~B}$ & T41078 & 1.26 \\
\hline KIAA1488 protein & T52311 & 1.26 \\
\hline Hypothetical protein MGC35048 & H98742 & 1.25 \\
\hline Aldehydede hydrogenase 1 family, member A1 & AA664101 & 1.25 \\
\hline Hypothetical protein MGC3133 & R78514 & 1.25 \\
\hline Integrin, alpha 9 & AA865557 & 1.24 \\
\hline Alcohol dehydrogenase 5 (class III), chi polypeptide & AA453859 & 1.24 \\
\hline YME1 (S. cerevisiae)-like 1 & N53511 & 1.24 \\
\hline Up-regulated by BCG-CWS & AA521384 & 1.24 \\
\hline KIAA0530 protein & T60850 & 1.24 \\
\hline Cntrl-7 & Cntrl-7 & 1.24 \\
\hline Transforming growth factor, beta 3 & AA040617 & 1.24 \\
\hline Inhibitor of growth family, member 3 & AA996230 & 1.24 \\
\hline KIAA1389 protein & AA464598 & 1.24 \\
\hline Calpastatin & T47601 & 1.24 \\
\hline Endothelial differentiation, lysophosphatidic acid G-protein-coupled receptor, 2 & AA193405 & 1.24 \\
\hline
\end{tabular}


(Continued)

N-acetylgalactosaminidase, alpha-

R25825

W68396

KIAA0096 protein

Sarcomeric muscle protein

AA418414

CD38 antigen (p45)

Angiogenin, ribonuclease, RNase A family, 5

R00276

1.23

Joined to JAZF1

AA682399

1.23

Tumor differentially expressed 2

$\mathrm{AI} 023724$

1.23

c-Myc target JPO1

R10545

1.22

N45440

1.22

RecQ protein-like (DNA helicase Q1-like)

Unactive progesterone receptor, $23 \mathrm{kD}$

Hydroxyacyl-Coenzyme Adehydrogenase/3-k

AA456585

1.22

N48708

T69767

$\mathrm{H} 40023$

1.22

KIAA1856 protein

Highly charged protein

Hypothetical protein FLJ20080

CCR4-NOT transcription complex, subunit 4

Peter Pan (Drosophila) homolog

Cell division cycle 25C

Transforming growth factor, beta 3

VAMP (vesicle-associated membrane protein)-associated protein B and C

Clathrin, heavy polypeptide (Hc)

Apolipoprotein B (including Ag (x) antigen)

H95716

1.22

1.22

W88693

AI000807

1.22

1.22

1.22

W95001

1.22

N76883

1.22

AA148402

1.22

H54366

H57779

1.22

1.22

1.22

AA427733 1.22

EPH receptor B6

Protocadherin 9

Hypothetical protein EDAG-1

AA609284

1.21

N63057

H57052

GTP-binding protein Rho 7

Uteroglobin

Putative ankyrin-repeat containing protein

Kh domain containing, RNA binding, signal transduction associated 3

cDNA clone IMAGE:4079668, partial cds

Major histocompatibility complex, class II, DP alpha 1

KIAA1105 protein

UDP-Gal:beta GlcNAc beta 1 ,4-galactosyltransferase, polypeptide 1

Homo sapiens clone IMAGE:5303499, mRNA

Semadomain, immunoglobulin domain (Ig), short basic domain, secreted, 3C

Amiloride binding protein 1 (amine oxidase (copper-containing))

Proteasome (prosome, macropain) inhibitor subunit1 (PI31)

B-factor, properdin

KIAA0746 protein

Glutamate-cysteine ligase, catalytic subunit

Pyruvate dehydrogenase kinase, isoenzyme 4

Cytochrome P450, subfamily IVB, polypeptide 1

Full length insert cDNA clone YI46G04

Myosin, light polypeptide 3

RAD51 (S. cerevisiae)-like 1

Chromosome 6 open reading frame 5

JunD proto-oncogene

AA700934

1.21

1.21

1.21

T63761

1.21

AA621188 1.21

AA456299 1.21

AA456629 1.20

AA278767 1.20

AA045176 1.20

AA284292 1.20

AA281793 1.20

AA042990 1.20

T46924

1.20

AA873845 $\quad 1.20$

AA401441 $\quad 1.20$

AA456569 1.20

H56069 1.20

AA169469 $\quad 1.20$

AA291484 1.19

R70541

1.19

AA192166

1.19

N70362

R78513

N66278

1.19

1.19

1.19

N94362

1.19

Interferon, gamma-inducible protein 30

AA630800

1.19

AA452824

1.19

KIAA1479 protein

AA069549

1.19

Microtubule-associated protein 7

R77251

1.19

Progestin induced protein

H27554

1.19

Bone morphogenetic protein 7

W73473

1.19

Cathepsin B 
8D6 antigen

AA434403

Chromosome 20 open reading frame 3

AA190882

1.18

Dual specificity phosphatase 10

AA056608

1.18

$\mathrm{N}$-acylsphingosine amidohydrolase (acid ceramidase)-like

W47576

1.18

Metallothionein 1E (functional)

T99140

1.18

Ribosomal protein S15a

Hypothetical protein FLJ20730

Inhibitor of DNA binding 1, dominant negative helix-loop-helix protein

AA411682

1.18

AA983410

1.18

Hypothetical protein FLJ20396

AA457158

1.18

AA486092

1.18

Activin A receptor, type II

AA682819

1.18

Cell death regulator aven

AA055221

ATP-binding cassette, sub-family B (MDR/TAP), member 10

AA434409

1.18

ADP-ribosylation factor-like 7

N35301

1.18

AA173981

1.17

CD2-associated protein

Monoamine oxidase B

Stromal interaction molecule 2

Signal transducer and activator of transcription 1, 91kDa

Hypothetical protein FLJ10875

CHK1 (checkpoint, S. pombe) homolog

Kynureninase (L-kynureninehydrolase)

AA682423

R28541

AA486367

1.17

1.17

N25240

1.17

1.17

N73242

1.17

H87471

Myeloid leukemia factor 1

AA707847

1.17

1.17

c-Myc target JPO1

Selectin L (lymphocyte adhesion molecule 1)

Toll-interleukin 1 receptor (TIR) domain containing adaptor protein

EGF-TM7-latrophilin-relatedprotein

AA406348

1.17

H00756

1.17

T95930

W72803

AA677534

1.17

1.17

1.17

Laminin, gamma 2

Methyl-CpG binding domain protein 1

AA459922

1.17

Hypothetical protein MGC2747

R91577

1.16

Paired box gene 8

Lymphocyte-specific protein tyrosine kinase

AA115328

1.16

1.16

AA469965

1.16

AA447746

1.16

Hypothetical protein

AA455284

1.16

Chemokine (C-C motif) receptor 1

Chromosome 5 open reading frame 7

AA036881

1.16

H26156

Hypothetical protein FLJ21069

Transforming, acidic coiled-coil containing protein

Arginase, type II

Chromosome 19 open reading frame 3

Adrenergic, beta-2-, receptor, surface

Major histocompatibility complex, classII, DR beta 4

p21/Cdc42/Rac1-activated kinase 1 (STE20 homolog, yeast)

Methionine adenosyltransferase II, beta

AA284277

1.16

AA456316

1.16

H17612

AA434159

1.16

1.16

H90431

1.16

W88967

1.16

AA173411

1.16

AA521303

1.15

N70841

1.15

Gamma-aminobutyric acid (GABA) B receptor, 1

AA070489

1.15

S100 calcium-binding protein A13

FOXJ2 forkhead factor

Telomeric repeat binding factor (NIMA-interacting) 1

AA902249

1.15

AA151295

1.15

AA461473

1.15

Nebulette

UDP glycosyltransferase 2 family, polypeptide B4

N53031

1.15

Hypothetical protein FLJ20079

Mal, T-cell differentiation protein 2

NY-REN-58 antigen

Mannosidase, alpha, class $1 \mathrm{~A}$, member 1

R99573

1.15

AA453783

1.15

W56770

AA489636

1.15

R74357

1.15

Integrin, beta 8

Glutathione S-transferase A2

Chaperonin containing TCP1, subunit 8 (theta)

T73468

AA630016 
(Continued)

Gene

Tumor necrosis factor (ligand) superfamily, member 10

WD40 repeat domain 11 protein

Spastin

Neural precursor cell expressed, developmentally down-regulated 9

Ath.-3

v-yes-1 Yamaguchi sarcoma viral related oncogene homolog

Serum response factor

Ankylosis, progressive (mouse) homolog

Macrophage stimulating 1 receptor (c-met-related tyrosine kinase)

Mitochondrial ribosomal protein S25

Cyclin M4

Non-metastatic cells 5

Hypothetical protein MGC17791

Growth arrest-specific 2

FYVE and coiled-coil domain containing 1

Membrane protein, palmitoylated 3 (MAGUK p55 subfamily member 3)

NAG18 protein

Hypothetical protein LOC283507

Prominin (mouse)-like 1

Keratin 13

RPB5-mediating protein

Transmembrane 4 superfamily member 6

Syndecan 2 (heparin sulfate proteoglycan 1, cell surface-associated, fibroglycan)

Hyaluronan-mediated motility receptor

Antigen identified by monoclonal antibody Ki-67

Syntaxin 11

TNF receptor-associated factor 3

G protein-binding protein CRFG

Protein kinase $C$, zeta

M5-14 protein

v-raf-1 murine leukemia viral oncogene homolog 1

Secreted frizzled-related protein 4

Asparagine synthetase

EGL nine (C. elegans) homolog 3

Sorting nexin 5

KIAA0475 gene product

Hypothetical protein DKFZp761K1423

Glycogenin

Hypothetical protein

Pleckstrin homology, Sec7 and coiled/coil domains, binding protein

Ataxin 3

Ubiquitin-like 1 (sentrin)

Replication protein A1 (70kD)

Eukaryotic translation initiation factor $5 \mathrm{~A}$

Phospholipase A2, group IIA

Palmitoyl-protein thioesterase 1(ceroid-lipofuscinosis, neuronal 1, infantile)

ST6 beta-galactosamide alpha-2,6-sialyltranferase 1

Secreted protein, acidic, cysteine-rich

Glutamate receptor, ionotropic, kainite 1

Zinc finger protein 200

p53-inducible p53 DINP1

Thrombopoietin

Hypothetical protein
Accession number

Fold change

H54629 1.15

AA134743

1.15

AA171421

1.15

T61428

1.14

Ath.-3

1.14

R83837

AA487973

1.14

H81907

1.14

1.14

AA173453

1.14

N71078

1.14

AA599138

1.14

AA129736

1.14

AA055992

1.14

R15728

1.14

1.14

W44685

1.14

N67878

1.14

AA035452

1.14

R40057

W60057

1.14

1.14

R63137

1.14

H87106

1.14

H64346

R10284

AA425973

1.14

1.14

1.14

R33851

1.14

H48096

H94929

AA458993

1.13

1.13

1.13

1.13

AA496948

1.13

1.13

AA486838

AA894927

AA150198

1.13

1.13

1.13

1.13

N73927

AA460826

1.13

1.13

1.13

AA446864

1.13

1.13

1.12

1.12

1.12

1.12

1.12

1.12

1.12

1.12

1.12

1.12

1.12

1.12

(Continued) 
(Continued)

Gene

Increased expression

DR1-associated protein 1 (negative cofactor 2 alpha)

Platelet-derived growth factor beta polypeptide

Clusterin

A disintegrin and metalloproteinase domain 12 (meltrin alpha)

Cullin 4B

Eukaryotic translation elongation factor

Arachidonate 5-lipoxygenase-activating protein

SEC63 protein

DEAD/H (Asp-Glu-Ala-Asp/His) box polypeptide

Non-metastatic cells 1, protein (NM23A)

Glutathione peroxidase 4 (phospholipids hydroperoxidase)

Cyclin E1

Polymerase (RNA) II (DNA directed) polypeptide I, $14.5 \mathrm{kDA}$ )

Carboxypeptidase D

Soares pregnant uterus NbHPU Homo sapiens cDNA clone

Ataxin 3

Host cell factor homolog

Mitochondrial ribosomal protein L2

Hypothetical protein FLJ12619

3'-phosphoadenosine 5'-phosphosulfatesynthase 1

Dual specific ityphosphatase 5

Angiopoietin-like 4

DKFZP586F1524 protein

$5^{\prime}$ nucleotidase (CD73)

Hypothetical protein

Alpha-actinin-2-associated LIM protein

Ribosomal protein S6 kinase, 90kDa, polypeptide 3

Signal transducer and activator of transcription 3

Dyskeratosis congenita1, dyskerin

API5-like 1

Protein phosphatase 1B (formerly 2C), magnesium-dependent, beta isoform

Coiled-coil domain containing 6

Eukaryotic translation initiation factor

Cyclin-dependent kinase 6

Non-metastatic cells 4

HYA22 protein

Telomeric repeat binding factor 2

Bruno-like4, RNA binding protein (Drosophila)

Ornithine decarboxylase 1

Beta-2-microglobulin

Eukaryotic translation initiation factor

Ariadne homolog, ubiquitin-conjugating enzyme E2 binding protein, 1 (Drosophila)

Fibrillarin

KIAA1813 protein

Golgi phosphoprotein 3 (coat-protein)

Protein phosphatase 1, regulatory (inhibitor) subunit 12A

Hypothetical protein PP591

Zinc finger protein 33a (KOX 31)

Pim-1 oncogene

Desmoglein 2

Thioredoxin-like2

ARP1 (actin-related protein 1, yeast) homolog A, centractin alpha

KIAA1275 protein
Accession number

Fold change

AA421977

1.10

T49539

1.10

AA130017

1.11

AA190993

1.11

AA780712

1.11

AA644657

1.11

H02307

1.12

N66750

1.12

H27564

1.12

AA644092

1.12

AA455197

1.12

T54121

1.12

AA777192

1.12

T56021

1.13

AA029997

1.13

AA702422

1.13

AA488367

1.13

N94366

1.13

AA418914

1.13

AA169832

1.13

W65461

1.13

W30988

1.13

AA428604

1.13

R60343

1.13

AA176785

1.13

AA972352

1.13

H55921

1.13

AA399410

1.13

AA052960

1.13

AA451935

1.13

H99661

1.13

AA699864

1.13

AA676471

1.13

H73724

1.14

H54417

1.14

R01638

AA676590

1.14

1.14

H92642

1.14

AA460115

1.14

AA670408

1.14

AA936783

1.14

AA188416

1.14

AA663986

1.14

AA456143

1.14

R63022

1.14

W32763

1.14

R38171

1.14

AA779415

1.14

N63635

1.14

T97257

1.14

H99205

1.14

AI014416

1.15

N70837 
(Continued)

\section{Gene}

IGF-II mRNA-binding protein 3

Janus kinase 1

DKFZP564A122 protein

Karyopherin alpha 3 (importin alpha 4)

Minichromosome maintenance deficient 5, cell division cycle 46 (S. cerevisiae)

E2F transcription factor 3

NS1-associated protein 1

Centromere protein F (350/400 kDa, mitosin)

Chromogranin B (secretogranin 1)

Actin related protein 2/3 complex, subunit 5, $16 \mathrm{kDa}$

Synovial sarcoma translocation

Transmembrane protease, serine 4

KIAA0205 gene product

Carcinoembryonic antigen-related cell adhesion molecule

Inositol polyphosphate phosphatase-like 1

Hypothetical protein

Cyclin-dependent kinase inhibitor 1B (p27, Kip1)

Transmembrane trafficking protein

Hypothetical protein from EUROIMAGE 1669387

CHK1 (checkpoint, S. pombe) homolog

v-Ki-ras 2 Kirsten rat sarcoma 2 viralon

Activated p21 cdc42 Hs kinase

Ras homolog gene family, member B

Amyloid beta precursor protein (cytoplasmic tail) binding protein 2

Myosin IXB

Helicase, lymphoid-specific

Eukaryotic translation initiation factor

Soares fetal liver spleen 1 NFLS Homo sapiens cDNA clone

Lectin, galactoside-binding, soluble, 3 binding protein

PAI-1 mRNA-binding protein

Retinoblastoma-binding protein 7

Transcription elongation factor B (SIII)

Ras-related C3 botulinum toxin substrate

Growth factor receptor-bound protein 10

Mitochondrial ribosomal protein S17

Misshapen/NIK-related kinase

Secreted frizzled-related protein 1

Chromosome 5 open reading frame 3

Frizzled (Drosophila) homolog 4

Signal peptidase complex subunit 3 homolog (S. cerevisiae)

Aldehyde dehydrogenase 7 family, member A1

Hypothetical protein MGC2383

FEM-1 (C. elegans) homolog b

Tissue inhibitor of metalloproteinase 2

Serum-inducible kinase

tRNA isopentenylpyrophosphate transferase 1

E1A binding protein p300

Corticotropin releasing hormone receptor

PTD008 protein

Sarcoma amplified sequence

RAN binding protein 1

Hypothetical protein FLJ10853

Hypothetical protein MGC5297

Farnesyl-diphosphate farnesyltransferase 1
Accession number

Fold change

AA187143

1.15

AA284634

1.15

N59690

1.15

AA668178

1.15

AA285155

1.15

N92519

1.15

AA186327

1.15

AA701455

1.15

W37769

1.15

W55964

1.15

N59206

1.15

AA999953

R91264

1.15

AA054073

1.15

1.15

AA279072

1.15

T70922

1.15

AA630082

1.15

W94609

1.15

R32354

1.15

AA463256

1.15

N95249

AA427891

1.15

1.15

N41062

1.16

AA046411

1.16

N51705

W25169

H54752

1.16

1.16

1.16

H80215

1.16

AA485353

AA487070

AA130591

AA630017

N54221

AA136336

AA733080

R10659

T68892

T74768

R26355

AA411686

AA101299

H95253

H82273

AA486280

AA460152

AA207083

N94428

H07088

AA427691

AA664211

R14822

T68430

R28412

AA679352
1.16

1.16

1.16

1.16

1.16

1.16

1.16

1.16

1.16

1.16

1.16

1.16

1.16

1.16

1.16

1.16

1.16

1.16

1.17

1.17

1.17

1.17

1.17

1.17

1.17

1.17

(Continued) 
RAB32, member RAS oncogene family

AA057378

Actinin, alpha1

AA669042

1.17

Protein tyrosine phosphatase

AA679180 1.17

Heterogeneous nuclear ribonucleoprotein U

T97593

1.18

Presenilins associated rhomboid-like protein

AA131464

1.18

Cntrl-1

Ribophorin I

Ribonucleotide reductase M2 polypeptide

Protein disulfide isomerase-related protein

Cntrl-1

1.18

AA127100

1.18

Bleomycin hydrolase

Eukaryotic translation elongation factor 2

AA187351

1.18

R02609

1.18

AA417881

1.18

Abl-interactor 2

R20379

1.18

N21334

1.19

ElaC (E.coli) homolog 2

AA455121

1.19

Protocadherin 1 (cadherin-like 1)

Rho GDP dissociation inhibitor (GDI) alpha

R77512

AA459400

1.19

Immediate early response 3

AA480815

1.19

Aldehyde dehydrogenase 18 family, member A1

R20638

1.19

Retinoic acid receptor, alpha

Peroxiredoxin 6

Frizzled (Drosophila) homolog 6

Dual specificity phosphatase 12

Peroxiredoxin 2

CDC14 (cell division cycle 14, S. cerevisiae)

AA705069

1.19

AA598874

1.19

T68333

1.19

AA485951

1.19

H68845

1.19

AA417319

1.20

Caspase recruitment domain protein 12

AA443290

1.20

Calnexin

Chaperonin containing TCP1, subunit 4 (delta)

AA126356

1.20

AA598637

1.20

Villin 1

Keratin 8

Fibronectin 1

Arrestin, beta 1

AA876039

1.20

AA598517

1.20

R62612

H20859

1.20

BENE protein

Chaperonin containing TCP1, subunit 7 (eta)

Potassium intermediate/small conductance calcium-activated channel, N4

AA778392

1.20

AA676588

1.21

AA443903

1.21

AA025275

1.21

Death-associated protein kinase 1

Amino acid transporter system A1

ATPase, $\mathrm{Na}^{+} / \mathrm{K}^{+}$transporting, beta 1 polypeptide

R66556

1.21

AA598814

1.21

Suppressor of G2 allele of SKP1 (S. cerevisiae)

AA416876

1.22

KIAA0226 gene product

Proteasome (prosome, macropain) 26S subunit, non-ATPase, 3

N51014

AA485052

1.22

R16760

1.22

Hepatitis B virus $x$ associated protein

cAMP responsive element binding protein 1

Ras homolog gene family, member E

H12320

W86282

H15274

R68360

1.22

1.22

1.22

1.22

Drebrin-like

Ribosomal protein L23

Olfactory receptor, family 2, subfamily A, member 9 pseudogene

AA463200

1.23

1.23

AA001222

1.23

AA922700

1.23

Microtubule-associated protein, RP/EB family, member 1

AA167823

1.23

CD27-binding (Siva) protein

\section{B-Actin}

ADP-ribosylation factor 4-like

Adrenergic, alpha-2A-, receptor

Stromal cell derived factor receptor 1

Protein tyrosine phosphatase, non-receptor type 2

Laminin, alpha 3

Protein kinase, cAMP-dependent, catalytic, beta

B-Actin

1.23

1.23

H15085

1.23

T48692

1.24

AA130671

1.24

AA428195

1.24

AA001432

1.24

AA018980 
(Continued)

Gene

Accession number

Fold change

Phosphofructokinase, muscle

Protein-L-isoaspartate (D-aspartate) O-m

Zinc finger RNA binding protein

Hsp70-interacting protein

Protein kinase, cAMP-dependent, catalytic, beta

Transmembrane 4 superfamily member 1

Cell growth regulatory with ring finger domain 1

Cot-2

Peptidylprolyl isomerase B (cyclophilin B)

Ribosomal protein S16

Hypothetical protein FLJ22060

Keratin 18

Transcribed locus

Lymphoidblast crisis oncogene

Succinate dehydrogenase complex, subunit D, integral membrane protein

Gamma-aminobutyric acid (GABA) A receptor, pi

Death-associated protein 6

Amplified in osteosarcoma

Placental growth factor, vascular endothelial growth factor-related protein

Protein kinase, AMP-activated, gamma 1 non-catalytic subunit

Splicing factor, arginine/serine-rich 8

\begin{tabular}{ll} 
AA099169 & 1.24 \\
T68518 & 1.24 \\
T50389 & 1.24 \\
AA401391 & 1.25 \\
AA459980 & 1.25 \\
AA487893 & 1.26 \\
AA676705 & 1.26 \\
Cot-1 & 1.26 \\
AA481464 & 1.26 \\
AA668301 & 1.26 \\
H56147 & 1.26 \\
AA664179 & 1.26 \\
H30547 & 1.26 \\
AA113166 & 1.26 \\
AA035384 & 1.27 \\
AA102670 & 1.27 \\
N73287 & 1.28 \\
AA013336 & 1.29 \\
AA130714 & 1.30 \\
AA018676 & 1.30 \\
AA702973 & 1.31 \\
AA427899 & 1.32 \\
AA490456 & 1.35 \\
N33274 & 1.36 \\
N63744 & 1.37 \\
H65676 & 1.49 \\
\hline
\end{tabular}

FK506-binding protein 1A (12kD)

Retinoic acid induced 14

Phosphoribosylaminoimidazole-carboxylase, -succinocarboxamidesynthetase

Hypothetical protein FLJ10468

Suppression of tumorigenicity 13 (coloncarcinoma) (Hsp70 interacting protein)

LNCaP Conditioned Media on HBME-1 Cells

Gene

Accession

Fold change

Decreased expression

Bromodomain adjacent to zinc finger domain, 2B

Sciellin

Dead ringer (Drosophila)-like 1

Chaperonin containing TCP1, subunit 6A (zeta 1)

Potassium inwardly-rectifying channel, subfamily J, member 13

Hypothetical protein MGC15523

Serine/threonine kinase 4

Hypothetical protein FLJ10890

KIAA1488 protein

Tissue factor pathway inhibitor 2

myosin, light polypeptide 3

Galactosidase, alpha

number

Kininogen

T41078 2.26

$\begin{array}{ll}\text { AA455012 } & 2.08\end{array}$

$\begin{array}{ll}\text { AA705382 } & 2.01\end{array}$

AA872690 1.98

H97186 1.92

AI016677 1.80

T94961 1.70

AA489394 1.59

T52311 1.59

AA399473 $\quad 1.58$

AA192166 1.54

AA251784 1.51

Increased expression

Minichromosome maintenance deficient 5, cell division cycle 46 (S. cerevisiae)

R89067

\section{REFERENCES}

1. Berruti A, Dogliotti L, Bitossi R, Fasolis G, Gorzegno G, Bellina M, Torta M, Porpiglia F, Fontana D, Angeli A. Incidence of skeletal complications in patients with bone metastatic prostate cancer and hormone refractory disease: Predictive role of bone resorption and formation markers evaluated at baseline. J Urol 2000;164(4):1248-1253.

2. Bubendorf L, Schopfer A, Wagner U, Sauter G, Moch H, Willi N, Gasser TC, Mihatsch MJ. Metastatic patterns of prostate cancer: An autopsy study of 1,589 patients. Hum Pathol 2000;31(5): $578-583$. 
3. Clark PE, Torti FM. Prostate cancer and bone metastases: Medical treatment. Clin Orthop Relat Res 2003(415 Suppl): S148-S157.

4. Roodman GD. Mechanisms of bone metastasis. N Engl J Med 2004;350(16):1655-1664.

5. Tantivejkul K, Kalikin LM, Pienta KJ. Dynamic process of prostate cancer metastasis to bone. J Cell Biochem 2004;91(4): 706-717.

6. Jacobs SC. Spread of prostatic cancer to bone. Urology 1983; 21(4):337-344.

7. Chen AC, Petrylak DP. Complications of androgen deprivation therapy in men with prostate cancer. Curr Oncol Rep 2004;6(3): 209-215.

8. Kasamon KM, Dawson NA. Update on hormone-refractory prostate cancer. Curr Opin Urol 2004;14(3):185-193.

9. Ryan CJ, Small EJ. Advances in prostate cancer. Curr Opin Oncol 2004;16(3):242-246.

10. Lehr JE, Pienta KJ. Preferential adhesion of prostate cancer cells to a human bone marrow endothelial cell line. J Natl Cancer Inst 1998;90(2):118-123.

11. Sikes RA, Nicholson BE, Koeneman KS, Edlund NM, Bissonette EA, Bradley MJ, Thalmann GN, Cecchini MG, Pienta KJ, Chung LW. Cellular interactions in the tropism of prostate cancer to bone. Int J Cancer 2004;110(4):497-503.

12. Hart CA, Brown M, Bagley S, Sharrard M, Clarke NW. Invasive characteristics of human prostatic epithelial cells: Understanding the metastatic process. Br J Cancer 2005;92(3):503-512.

13. Scott LJ, Clarke NW, George NJ, Shanks JH, Testa NG, Lang SH. Interactions of human prostatic epithelial cells with bone marrow endothelium: Binding and invasion. Br J Cancer 2001; 84(10):1417-1423.

14. Taichman RS, Cooper C, Keller ET, Pienta KJ, Taichman NS, McCauley LK. Use of the stromal cell-derived factor-1/CXCR4 pathway in prostate cancer metastasis to bone. Cancer Res 2002;62(6):1832-1837.

15. Kumar R, Fidler IJ. Angiogenic molecules and cancer metastasis. In Vivo 1998;12(1):27-34.

16. Nicholson B, Theodorescu D. Angiogenesis and prostate cancer tumor growth. J Cell Biochem 2004;91(1):125-150.

17. Barrett JM, Mangold KA, Jilling T, Kaul KL. Bi-directional interactions of prostate cancer cells and bone marrow endothelial cells in three-dimensional culture. Prostate 2005;64(1):75-82.

18. Tseng GC, Oh MK, Rohlin L, Liao JC, Wong WH. Issues in cDNA microarray analysis: Quality filtering, channel normalization, models of variations, and assessment of gene effects. Nucleic Acids Res 2001;29(12):2549-2557.

19. Cosgrove D, Rodgers K, Meehan D, Miller C, Bovard K, Gilroy A, Gardner H, Kotelianski V, Gotwals P, Amatucci A, Kalluri R. Integrin alpha1beta1 and transforming growth factor-beta1 play distinct roles in alport glomerular pathogenesis and serve as dual targets for metabolic therapy. Am J Pathol 2000;157(5): 1649-1659.

20. Lammerts E, Roswall P, Sundberg C, Gotwals PJ, Koteliansky VE, Reed RK, Heldin NE, Rubin K. Interference with TGF-beta1 and -beta3 in tumor stroma lowers tumor interstitial fluid pressure independently of growth in experimental carcinoma. Int J Cancer 2002;102(5):453-462.

21. Muraoka RS, Dumont N, Ritter CA, Dugger TC, Brantley DM, Chen J, Easterly E, Roebuck LR, Ryan S, Gotwals PJ, Koteliansky $\mathrm{V}$, Arteaga CL. Blockade of TGF-beta inhibits mammary tumor cell viability, migration, and metastases. J Clin Invest 2002; 109(12):1551-1559.
22. Quan T, He T, Kang S, Voorhees JJ, Fisher GJ. Ultraviolet irradiation alters transforming growth factor beta/smad pathway in human skin in vivo. J Invest Dermatol 2002;119(2):499506.

23. Wikstrom P, Damber J, Bergh A. Role of transforming growth factor-beta1 in prostate cancer. Microsc Res Tech 2001;52(4):411419.

24. Lee C, Sintich SM, Mathews EP, Shah AH, Kundu SD, Perry KT, Cho JS, Ilio KY, Cronauer MV, Janulis L, Sensibar JA. Transforming growth factor-beta in benign and malignant prostate. Prostate 1999;39(4):285-290.

25. Akhurst RJ, Derynck R. TGF-beta signaling in cancer-A doubleedged sword. Trends Cell Biol 2001;11(11):S44-S51.

26. Bello-DeOcampo D, Tindall DJ. TGF-betal/Smad signaling in prostate cancer. Curr Drug Targets 2003;4(3):197-207.

27. RayChaudhury A, D'Amore PA. Endothelial cell regulation by transforming growth factor-beta. J Cell Biochem 1991;47(3):224229.

28. Massague J. TGF-beta signal transduction. Annu Rev Biochem 1998;67:753-791.

29. Piek E, Heldin CH, Ten Dijke P. Specificity, diversity, and regulation in TGF-beta superfamily signaling. FASEB J 1999; 13(15):2105-2124.

30. Attisano L, Carcamo J, Ventura F, Weis FM, Massague J, Wrana JL. Identification of human activin and TGF beta type I receptors that form heteromeric kinase complexes with type II receptors. Cell 1993;75(4):671-680.

31. ten Dijke $\mathrm{P}$, Yamashita $\mathrm{H}$, Sampath TK, Reddi AH, Estevez M, Riddle DL, Ichijo $\mathrm{H}$, Heldin $\mathrm{CH}$, Miyazono $\mathrm{K}$. Identification of type I receptors for osteogenic protein-1 and bone morphogenetic protein-4. J Biol Chem 1994;269(25):1698516988.

32. Liu F, Ventura F, Doody J, Massague J. Human type II receptor for bone morphogenic proteins (BMPs): Extension of the twokinase receptor model to the BMPs. Mol Cell Biol 1995;15(7): 3479-3486.

33. Ebner R, Chen RH, Lawler S, Zioncheck T, Derynck R. Determination of type I receptor specificity by the type II receptors for TGF-beta or activin. Science 1993;262(5135):900902.

34. Wikstrom P, Stattin P, Franck-Lissbrant I, Damber JE, Bergh A. Transforming growth factor beta1 is associated with angiogenesis, metastasis, and poor clinical outcome in prostate cancer. Prostate 1998;37(1):19-29.

35. Tuxhorn JA, McAlhany SJ, Yang F, Dang TD, Rowley DR. Inhibition of transforming growth factor-beta activity decreases angiogenesis in a human prostate cancer-reactive stroma xenograft model. Cancer Res 2002;62(21):6021-6025.

36. Gohongi T, Fukumura D, Boucher Y, Yun CO, Soff GA, Compton C, Todoroki T, Jain RK. Tumor-host interactions in the gallbladder suppress distal angiogenesis and tumor growth: Involvement of transforming growth factor beta1. Nat Med 1999;5(10):1203-1208.

37. Tang B, de Castro K, Barnes HE, Parks WT, Stewart L, Bottinger EP, Danielpour D, Wakefield LM. Loss of responsiveness to transforming growth factor beta induces malignant transformation of nontumorigenic rat prostate epithelial cells. Cancer Res 1999;59(19):4834-4842.

38. Tu WH, Thomas TZ, Masumori N, Bhowmick NA, Gorska AE, Shyr Y, Kasper S, Case T, Roberts RL, Shappell SB, Moses HL, Matusik RJ. The loss of TGF-beta signaling promotes prostate cancer metastasis. Neoplasia 2003;5(3):267-277. 
39. Bonewald LF, Wakefield L, Oreffo RO, Escobedo A, Twardzik DR, Mundy GR. Latent forms of transforming growth factor-beta (TGF beta) derived from bone cultures: Identification of a naturally occurring $100-\mathrm{kDa}$ complex with similarity to recombinant latent TGF beta. Mol Endocrinol 1991;5(6):741751.

40. Munger JS, Harpel JG, Gleizes PE, Mazzieri R, Nunes I, Rifkin DB. Latent transforming growth factor-beta: Structural features and mechanisms of activation. Kidney Int 1997; 51(5): 1376-1382.

41. Hart CA, Scott LJ, Bagley S, Bryden AA, Clarke NW, Lang SH. Role of proteolytic enzymes in human prostate bone metastasis formation: In vivo and in vitro studies. Br J Cancer 2002;86(7): $1136-1142$

42. Annes JP, Munger JS, Rifkin DB. Making sense of latent TGFbeta activation. J Cell Sci 2003;116(Pt 2):217-224. 